\title{
Preliminary Phytochemical Screening and Antioxidant Content of Leaves and Berries of Makoi
}

\author{
Reeta Solanki ${ }^{1}$, Diksha Gupta ${ }^{2}$ and Neelam Chaturvedi ${ }^{3 *}$ \\ ${ }^{1}$ Nutritionist, Rana Hospital, Delhi Road, Bhoor Bulandashahr, Uttar Pradesh, India(203001) \\ ${ }^{2}$ Research scholar, ${ }^{3 *}$ Associate professor, Department of Food Science and Nutrition, Banasthali \\ Vidyapith, Dist-Tonk, Rajasthan, India (304022) \\ *E-mail: neelam295chaturvedi@rediffmail.com
}

\begin{abstract}
Makoi is well- known medicinal herb found in India that have bioactive components which attribute to a strong free radical scavenging activity and can modulate many diseases. In the view of the above research facts, the present investigation was undertaken to study the phytochemical screening (alkaloids, tannins, flavonoids, saponins, glycosides, phenolic compound, and phytosterols) and antioxidant potential (total phenolic content, total flavonoids content and tannins content) of both leaves and berries of Makoi plant. The study results revealed that Phytochemical screening of both leaves and berries showed the presence of all phytochemicals; alkaloids, tannins, flavonoids, saponins, glycosides, phenolic compound) except phytosterols. Whereas, antioxidant potential showed that leaves of Makoihad significantly higher content of total phenols $(12.16 \pm 0.05 \mathrm{mgGAE} / \mathrm{g})$, total flavonoids $(2.82 \pm 0.05 \mathrm{mgQE} / \mathrm{g})$ and tannins $(1.25 \pm 0.05 \mathrm{mg} / \mathrm{g})$ as compared to berries. Thus, the result of this study concluded that the leaves and berries of Makoi contain appreciable amount of antioxidants, hence can be beneficial to treat the various metabolic and degenerative diseases.
\end{abstract}

Keywords: Antioxdant Potential, Makoi, Phytochemical Screening

Paper cited: Solanki, R., Gupta, D. and Chaturvedi. N. (2018). Preliminary Phytochemical Screening and Antioxidant Content of Leaves and Berries of Makoi. South Asian Journal of Food Technology and Environment, 4(1): 622-627.

\section{Introduction}

Free radicals are highly reactive molecules or chemical species capable of independent existence. The cytotoxic effect of free radicals is deleterious to mammalian cells and mediates the pathogenesis of many chronic diseases such as cardiovascular diseases, diabetes mellitus, cancer etc. Therefore, medicinal plants are believed to be an important source of new chemical substances with potential therapeutic effects and more than $80 \%$ of population of developing countries is dependent on traditional folk medicine therapies for treating their ailments. Most of the plants have protective biochemical functions of naturally occurring antioxidants in the cells (Patel et al., 2009). Several pharmaceutically active constituents of plants have been assessed to defend against oxidative damage by inhibiting or quenching free radicals and reactive oxygen species. Naturally occurring antioxidants in plant cells include peptide defence mechanisms which are catalases, peroxidases, superoxide dismutase, glutathione, proteins, tocopherols, flavonoids, phenolics, nitrogen compounds, carotenoids and chlorophyll derivatives (Kumar et al., 2008).

The plant Makoi (Solanum nigrum Linn) is commonly known as black night shade in English, Kachchipandu in Telugu andMunatakali in Tamil, belongs to the Solanaceae family (Jimoh et al., 2010).It is an annual weed that grow up to $60 \mathrm{~cm}$ tall, branched, erect, usually grows in moist habitats in different kinds of soil, including 
dry, stony, shallow, or deep soils, crop fields. It can be cultivated in tropical and subtropical agro climatic regions. The stem may be smooth or bear small hairs (trichomes), the flowers usually white in colour, have five regular parts and are up to $0.8 \mathrm{~cm}$ wide. The leaves are alternate, opaque, ovate, smooth, finely hairy, matt and dark in colour with irregularly toothed wavy margin. The berries are globular, dark green, matt berries 5-13 mm across, matt black when ripe, which contain many flattened finely pitted, yellow to dark brown woody seeds approximately $1.5 \mathrm{~mm}$ long.

It has an extensive range of medicinal value due to the presence of protein, vitamins and minerals and variety of natural bioactive compounds such as steroidal lactones, glycosides, alkaloids and flavonoids. Thus, it is commonly used in Ayurvedic medicine in India as tonic or supplement for the treatment and prevention of metabolic disorders. The herb also possesses antiseptic, antidysenteric and antidrug of cardiac, skin diseases, psoriasis and inflammation of kidney.The fruits are used as a tonic, laxative, appetite stimulant; and also for treating asthma and "excessive thirst" (Al-Daihan, 2008). The extracts of leaves are also used to alleviate liver-related ailments, including jaundice. It is also used in the Oriental systems of medicine for various purposes-as an antitumorigenic, antioxidant (Lee and Lim, 2003), antiinflammatory (Zakaria et al., 2006), hepatoprotective (Raju et al., 2003) and antipyretic agent (Kaushik et al., 2009).Hence, in the light of the above research facts, the present investigation was undertaken with the objective to study the preliminary phytochemical screening and antioxidant potential of leaves and berries of makoi.

\section{Materials and methods}

\section{Sample collection and preparation of powder}

The leaves and berries of makoi were collected from the Krishi Vigyan Kendra of
Bulandshahr, Uttar Pradesh. The leaves and berries were washed in tap water and shade dried after which they were reduced into fine powder by grinding and packed into air tight container for further analysis.

\section{Preparation of aqueous extract of leaves and berries of Makoi}

$20 \mathrm{~g}$ of powdered plant material was kept in $200 \mathrm{ml}$ conical flask and add $100 \mathrm{ml}$ of distilled water. The mouth of the conical flask was covered with the aluminium foil and kept in a reciprocating shaker for 25 minutes for continuous agitation at $150 \mathrm{rpm}$ for thorough mixing. Then extracts were filtered by using muslin cloth followed by Whatman filter paper No. $42(125 \mathrm{~mm})$. The contained was filtered by using rotator vacuum evaporator with the water bath temperature of $65^{\circ} \mathrm{C}$ and finally the residues were collected and used for the analysis (Nagappan, 2012).

\section{Preliminary phytochemical screening}

The filtrate of leaves and berries powder were tested for the presence of various bioactive compounds namely alkaloids (Mayer's reagents), tannins (Ferric chloride test), flavonoids (Shonoda test), saponins (Froth Test), glycosides (Legal's test), phenolic compound (Ferric Chloride) and phytosterols (Libermann- Burchard's Test) (Oluduro, 2012).

\section{Determination of antioxidants content}

Total phenols content: Total phenols were determined by Folin-Ciocalteu reagent using gallic acid (GA) as the standard. The leaves and berries extract or processing water $(50 \mu \mathrm{l})$, distilled water $(3 \mathrm{ml}), 250 \mu \mathrm{l}$ of FolinCiocalteu reagent solution and $7 \% \mathrm{NaCO}_{3}(750$ $\mu 1)$ were mixed in a tube and incubated for 8 $\mathrm{min}$ at the room temperature. A dose of $950 \mu \mathrm{l}$ of distilled water was added. The mixture was allowed to stand for 2 hours at the room temperature. The absorbance was measured at $765 \mathrm{~nm}$ against a reagent blank, which was composed of same reagents except that $50 \mu 1$ of distilled water. The total phenolic content was expressed as gallic acid equivalents (mg 
of $\mathrm{GAE} / \mathrm{g}$ sample) through the calibration curve of gallic acid. Linearity range of calibration curve was $50-1000 \mu \mathrm{g} / \mathrm{ml}(\mathrm{r}=0.99)$ (McDonald et al., 2001).

Total flavonoids content: The total flavonoids were determined using a colorimetric method, as described by Shiva et al., 2007. Briefly $0.1 \mathrm{ml}$ of the methonolic extract was diluted with $0.9 \mathrm{ml}$ of methanol. Aliquots of diluted extracts $(0.5 \mathrm{ml})$ were added to test tubes and mixedwith $0.1 \mathrm{ml}$ of $10 \%$ aluminum nitrate, $0.1 \mathrm{ml}$ of $1 \mathrm{M}$ aqueous potassium acetate and $4.3 \mathrm{ml}$ of methanol. After standing for $40 \mathrm{~min}$ at room temperature, the absorbance of the reaction mixture was measured at $415 \mathrm{~nm}$. Quercetin was used as a standard compound in the range of 50-200 $\mu \mathrm{g} / \mathrm{ml}$ concentration to construct a standard curve. The amount of total flavonoids was expressed as quercetin equivalent in $\mathrm{mg} / \mathrm{g}$ of dried extract.

Tannins content: The tannin content of the leaves and berries was assessed using the Folin-Denis reagent (FDR) (Rahate et al., 2013). A known quantity of finely ground sample of leaves and berries was extracted in $100 \mathrm{ml}$ of distilled water by boiling gently for $30 \mathrm{~min}$. the extract was centrifuged for $20 \mathrm{~min}$ and the supernatant was made to a known volume. An aliquot of 2-4 $\mathrm{ml}$ was pipette into $25 \mathrm{ml}$ volumetric flask and $0.5 \mathrm{ml}$ of FDR $1 \mathrm{~N}$ solution and $1 \mathrm{ml}$ of sodium carbonate solution was made up and allowed to stand for 1 hour. The turbidity was eliminated by filtering. The absorbance of color developed was measured at $710 \mathrm{~nm}$. The concentration of tannic acid expressed as $\mathrm{mg} / \mathrm{g}$ sample.

\section{Statistical analysis:}

The results obtained were expressed as Mean $\pm S D$ and Paired ' $t$ '-Test of three determinations and also statistically analyzed to ascertain its significance. The significance was estimated at ( $\mathrm{p} \leq 0.05$ level).

\section{Results and Discussion}

Table 1 depicts that the phytochemical screening of both leaves and berries of Makoi.
Leaves and berries of Makoi contain all phytochemicals such as alkaloids, tannins, flavonoids, saponins, glycosides and phenolic compounds except phytosterols. The results in the study are in consonance with earlier report of Djaafar and Ridha, (2013) who noted the presence of alkaloids, tannins, flavonoids, saponins, glycosides and coumarines in both leaves and berries except terpenoids in leaves. Oyeyemi et al., (2015) noted the presence of alkaloids, saponins, flavonoids, tannins, phenols, steroids, triterpenoids and the absence of glycosides in the berries of Solanum anguivi. It has been found that these phytochemicals act as an anti-inflammatory, anti-hypertensive, and anti-microbial. Alkaloids are plant-derived compound that is responsible to possess the antibacterial activity (Mantle et al., 2000). Saponins and tannins also exhibit cytotoxic effects and growth inhibition making them suitable as tumor inhibiting agents (Akidanhunsi and Salowu, 2005).As a key source of flavonoids and phenolic compounds, leaves and berries of Makoiare proposed to have antioxidant properties. The apparent antioxidant and antimutagenic activities of the plant further suggest their potential usefulness in cancer transfer into cytosol by phenolic binding or insertion into the transporters of the outer membrane of the cell (Haskell et al., 2004).

Table 2 depicts that the antioxidant activity of both leaves and berries of Makoi The total phenols content $(\mathrm{mgGAE} / \mathrm{g})$ of leaves and berries were 12.16 \pm 0.05 and $11.96 \pm 0.05$ respectively. This shows that leaves were significantly increased by $2.13 \%$ atp $\geq 0.05$ level when compared toberries. The values obtained compared favorably with leaves of Solanum nigrum $(11.94 \mathrm{mg} / \mathrm{g})$ reported by Akuwugbo et al., (2008). Likewise, the study reported by Govindan et al., (2012) that berries of Solanum muricatum contain (13.99 $\pm 0.50 \mathrm{mg} \mathrm{GAE} / \mathrm{g}$ ) of phenol which is agreement with the present study. 
Table 1: Phytochemical screening of aqueous extracts of leaves and berries of Makoi

\begin{tabular}{|l|l|c|c|}
\hline Phytochemicals & \multicolumn{1}{|c|}{ Reagents/Methods adopted } & Leaves & Berries \\
\hline Alkaloids & Mayer's reagents & $+\mathrm{ve}$ & $+\mathrm{ve}$ \\
\hline Tannins & Ferric chloride test & $+\mathrm{ve}$ & $+\mathrm{ve}$ \\
\hline Flavonoids & Shinoda test & $+\mathrm{ve}$ & $+\mathrm{ve}$ \\
\hline Saponins & Froth test & $+\mathrm{ve}$ & $+\mathrm{ve}$ \\
\hline Glycosides & Legal's test & $+\mathrm{ve}$ & $+\mathrm{ve}$ \\
\hline Phenols & Ferric chloride & $+\mathrm{ve}$ & $+\mathrm{ve}$ \\
\hline Phytosterols & Liebermann - Bur chard's Test & $-\mathrm{ve}$ & $-\mathrm{ve}$ \\
\hline
\end{tabular}

- Absence, + Present

Table 2: Antioxidant activity of leaves and berries of Makoi

\begin{tabular}{|l|c|c|}
\hline Antioxidants & Leaves & Berries \\
\hline $\begin{array}{l}\text { Total phenols content } \\
(\mathrm{mg} \text { GAE/g) }\end{array}$ & $12.16 \pm 0.0 .5$ & $11.96 \pm 0.05^{*}(2.13 \% \downarrow)$ \\
\hline $\begin{array}{l}\text { Total flavonoids content } \\
(\mathrm{mg} Q \mathrm{~g} / \mathrm{g})\end{array}$ & $2.82 \pm 0.05$ & $1.62 \pm 0.01 *(22.1 \% \downarrow)$ \\
\hline $\begin{array}{l}\text { Tannins content } \\
(\mathrm{mg} / \mathrm{g})\end{array}$ & $1.25 \pm 0.05$ & $0.65 \pm 0.01 *(48.0 \% \downarrow)$ \\
\hline
\end{tabular}

The estimated values for total flavonoids content $(\mathrm{mgQE} / \mathrm{g})$ of both leaves and berries were $2.82 \pm 0.05$ and $1.62 \pm 0.01$ respectively. This shows leaves were significantly increased by $22.1 \%$ at $\mathrm{p} \geq 0.05$ level when compared with berries. The values obtained compared positively with leaves $(2.31 \pm 0.47 \mathrm{mg} / \mathrm{g})$ and berries of Solanum nigrum $(2.11 \pm 0.16 \mathrm{mg} / \mathrm{g})$ reported by Gbadamosi and Afolayan, (2016). Whereas, the study reported by Alam et al.,(2012) that ethanol extract of Solanum nigrum berries contain $0.62 \mathrm{mgQE} / \mathrm{g}$ of flavonoids which is lower than the data observed by present study.

The tannins content $(\mathrm{mg} / \mathrm{g})$ of leaves and berries were $1.25 \pm 0.05$ and $0.65 \pm 0.01$ respectively. This shows that leaves were significantly increased by $48.0 \%$ at $\mathrm{p} \geq 0.05$ level when compared with berries. The values for tannins in this study were comparatively higher with leaves of Solanum nigrum $(0.14 \pm 0.01 \mathrm{mg} / \mathrm{g})$ reported by Akuwugbo et al.,(2007) and with berries of Soalnum anguivi $(0.17 \pm 0.07 \mathrm{mg} / \mathrm{g})$ reported by Oyeyemi et al., (2015)

\section{Conclusion}

On the basis of present results it can be concluded that leaves and berries of Makoi bear potent antioxidant activity. The antioxidants act as defense mechanism that protects against oxidative damage, and include compounds to remove or repair damaged molecules and sufficient intake of antioxidants is supposed to protect against diseases. The phytochemical antioxidants have potent potential to neutralize free radicals or oxidants responsible for the cell damage. Thus, the present study scientifically validates and strengthens the candidature of Makoi in the preparation of medicinal aids to combat the wide spectrum of myriad diseases arising due to oxidative stress.

\section{Acknowledgement}

Authors are thankful to Prof. Aditya Shastri (Vice Chancellor) of Banasthali Vidyapith for providing all the required lab facilities in Food Science and Nutrition 
department that helped us for the successful completion of the project work.

\section{Conflict of interest statement}

of interest.

We declared that we have no conflict

\section{References}

1. Akidanhunsi, A.A. and Salowu, S.O. (2005). Phytochemical screening and nutritional -antinutrient composition of selected Tropical green leafy vegetables. African Journal of Biochemistry, 4: 497-501.

2. Akubugwo, I.E., Obasi, A.N. and Ginika, S.C. (2007). Nutritional potential of the leaves and seeds of Black nightshade-Solanum nigrum from Afikpo-Nigeria. Pakistan Journal of Nutrition, 6(4): 323-326.

3. Akubugwo, I.E., Obasi, N.A., Chinyere, G.C. and Ugbogu, A.E. (2008). Mineral and phytochemical contents in leaves of Amaranthus hybridus L and Solanum nigrum L. subjected to different processing methods. African Journal of Biochemistry Research, 2(2):40-44.

4. Alam, N.M., Roy, S., Anisuzzaman, M.S. and Rafiquzzaman, M. (2012).Antioxidant activity of the ethanolic extracts of leaves, stems and fruits of Solanum nigrum. Research Letter, 2(3): 67-71.

5. Al-Daihan, S.(2008). Measurement of selected enzymatic activities in Solanum nigrum- treated Biomphalaria arabica snails. Journal of Applied Sciences, 8: 881-885.

6. Djaafar, Z. and Ridha, M.O. (2013). Phytochemical study of selected medicinal plant, Solanum nigrum, the Algerian desert. International Letters of Chemistry, Physics and Astronomy, 20: 25-30.

7. Gbadamosi, I.T. and Afolayan, A.J. (2016). In vitro anti-radical activities of extracts of Solanum nigrum L. from
South Africa. Journal of Applied Biosciences, 98: 9240-9251.

8. Govindan, S., Marimuthu, S.P., Rajan, B.I.S. and Sabapathy, V. (2012). Antioxidant activity of ripe and unripe pepino fruit (Solanum muricatum Aiton). Journal of Food Science, 77(11): 1131-1135.

9. Haskell, M.J., Janil, K.M., Hassan, F., Person, J.M., Hersain, M.I., Fuchs, C.J. and Brown, K.N. (2004). Daily consumption of Indian spinach or sweet potatoes has a positive effect on total body vitamin stores in Bangladesh man. American Journal of Clinical Nutrition, 80: 705-14.

10. Jimoh, F.O., Adedapo, A.A. and Afolayan, A.J. (2010). Comparison of the nutritional value and biological activities of the acetone, methanol and water extracts of the leaves of Solanum nigrum and Leonotis leonorus. Food and Chemical Toxicology, 48:964-71.

11. Kaushik, D., Jogpal, V., Kaushik, P., Lal, S., Saneja, A., Sharma, C. and Aneja, K.R. (2009) Evaluation of activities of Solanum nigrum fruit extract. Archives of Applied Science Research, 1(1): 43-50.

12. Kumar, P.S., Sucheta, S., Deepa, V.S., Selvamani, P. and Latha, S. (2008). Antioxidant activity in some selected Indian medicinal plants. African Journal of Biotechnology, 7(12): 1826-1828.

13. Lee, S.J. and Lim, K.T. (2003). Antioxidative effects of glycoprotein isolated from Solanum nigrum $\mathrm{L}$ on oxygen radicals and its cytotoxic effects on the MCF-7 cell. Journal of Food Science, 68: 466-470.

14. Mantle, D., Lennard, T.W. and Pickering, A.T. (2000). Therapeutic application of medicinal plants in the treatment of breast cancer: a review of their pharmacology efficacy and tolerability. Adverse Drug Reactions 
and Toxicological Reviews, 19: 223240.

15. McDonald, S., Prenzler, P.D., Antolovich, M. and Robards, K. (2001). Phenolic content and antioxidant activity of olive extracts. Food Chemistry, 73(1): 73-84.

16. Nagappan, R. (2012). Evaluation of aqueous and methnol extracts of bioactive medicinal plant, Cassia didymobotrya (Fresenius) Irwin \& Barne by against immature stages of filarial vector, Culexquinques fasciatus say (Diptera: Culiidae). Asian Pacific Journal of Tropical Biomedicine, 2: 707-711.

17. Oluduro, A.O. (2012). Evaluation of antimicrobial properties and nutritional potentials of Moringa oleifera Lam. leaf in South-Western Nigeria. Malaysian Journal of Microbiology, 8(2): 59-67.

18. Oyeyemi, S.D., Ayeni, M.J., Adebiyi, A.O., Ademiluyi, B.O., Tedela, P.O. and Osuji, I.B. (2015). Nutritional quality and phytochemical studies of Solanumanguivi(Lam.) fruits. Journal of Natural Sciences Research, 5(4): 99-105.

19. Patel, S., Gheewala, N., Suthar, A. and Shah, A. (2009). In-vitro cytotoxicity activity of Solanum nigrum extracts against Hela cell lines and Vero cell lines. International Journal of Pharmacy and Pharmaceutical Sciences, 1(1): 38-46.

20. Rahate, K.P., Padma, R., Parvathy, N.G. and Renjith, V. (2013). Quantitative estimation of tannins, phenols and methanolic extract of Imperata cylindrical. International Journal of Research and Pharmaceutical Sciences, 4: 73-77.

21. Raju, K., Anbuganapathi, G. and Gokulakrishnan, V. (2003). Effect of dried fruits of Solanum nigrum L against CCl4-induced hepatic damage in rats. Biological and Pharmaceutical Bulletin, 26: 1618-1619.

22. Shiva, M., Mohammad, S., Manoochehr, H., Yaghoub, A. and Seyed, E.S.E. (2007). Antioxidant power of Iranian propolis extract. Food Chemistry, 103: 729-733.

23. Zakaria, Z.A., Gopalan, H.K. and Zainal, H. (2006). Anti-nociceptive, anti-inflammatory and antipyretic effects of Solanum nigrum chloroform extract in animal models. Journal of the Pharmaceutical Society of Japan, 126: 1171-1178.

$\begin{array}{ll}\text { Received } & \text { : Jan, 2018 } \\ \text { Revised } & \text { : March, 2018 } \\ \text { Published } & \text { : June, 2018 }\end{array}$

